\title{
IMPLEMENTASI CORPORATE GOVERNANCE (CG): DALAM MENINGKATKAN KINERJA PERUSAHAAN
}

\author{
Suhadi \\ Sekolah Tinggi Agama Islam Negeri Kudus \\ (salwalubna44@gmail.com)
}

\begin{abstract}
Corporate Governance (CG) merupakan tata kelola perusahaan yang menjelaskan hubungan antara berbagai partisipan dalam perusahaan. Tata kelola perusahaan yang baik tentu menjadi ekspektasi oleh stakeholders, yaitu keberhasilan dalam menentukan arah dan kinerja perusahaan. Corporate governance berhubungan erat dengan bagaimana para pemilik modal atau investor yakin bahwa manajer akan memberikan keuntungan bagi mereka, sehingga bagaimana para investor bias mengontrol para manajer. Corporate Governance (CG) yang mengandung empat unsur penting, yaitu keadilan, transparansi, pertanggungjawaban dan akuntabilitas, diharapkan dapat menjadi suatu solusi dalam meminimalisir konflik keagenan. Hubungan implisit antara pemegang saham dan manajer hanya salah satu dari hubungan keagenan, hubungan keagenan yang lain misalnya hubungan antara manajer dengan berbagai kelompok yang memiliki kepentingan terhadap perusahaan.
\end{abstract}

Keywords: Corporate Governance (CG, ), Prinsip-Prinsip dan Mekanisme Corporate Governance

\section{A. PENDAHULUAN}

Corporate Governance (CG) atau tata kelola perusahaan diera sekarang sudah menjadi keharusan dalam dunia bisnis. Corporate Governance (CG) di Indonesia mulai ramai dibicarakan ketika muncul diera reformasi, dimana pada waktu itu krisis melanda Indonesia salah satunya diakibatkan minimnya penerapan corporate governance. Sebelum reformasi transparasi pengelolaan perusahaan sangat kurang sehingga kontrol publik menjadi sangat lemah dan para pemegang saham mayoritas mendominasi pengaruhnya terhadap manajemen perusahaan sangat terasa sehingga menimbulkan konflik kepentingan.

Teori keagenan menyebutkan bahwa untuk mengatasi masalah 
ketidakselarasan kepentingan salah satunya adalah melalui pengelolaan perusahaan yang baik (good corporate governance). Corporate governance merupakan suatu mekanisme yang digunakan untuk memastikan bahwa supplier keuangan dari perusahaan memperoleh pengembalian dari kegiatan yang dijalankan oleh manajer, atau dengan kata lain bagaimana supplier keuangan perusahaan melakukan control terhadap manajer. Good corporate governance mensyaratkan suatu pengelolaan yang baik dalam sebuah organisasi (Hastuti, 2005: 30).

Pengukuran kinerja perusahaan dan manajemen dilihat dari besarnya laba yang dihasilkan perusahaan. Laba yang diungkapkan pada laporan keuangan perusahaan merupakan laba yang diukur dengan dasar akrual. Pengelolaan laba dengan dasar akrual memungkinkan manajemen untuk merekayasa laba atau earnings management. Perekayasaan laba dilakukan untuk menaikkan atau menurunkan angka akrual dalam laporan laba rugi yang bertujuan menunjukkan kinerja manajemen yang bagus. Menurut Boediono, (2005: 172-191), bahwa tindakan earnings management telah memunculkan beberapa kasus skandal pelaporan akuntansi yang secara luas diketahui, antara lain Enron, Merck, World Com dan mayoritas perusahaan lain di Amerika Serikat. Beberapa kasus yang terjadi di Indonesia, seperti PT. Lippo Tbk dan PT. Kimia Farma Tbk juga melibatkan pelaporan keuangan (financial reporting) yang berawal dari terdeteksinya adanya manipulasi.

Chan et.al, dalam Siallagan dan Machfoedz (2006: 35-38) menguji apakah return saham yang akan datang akan merefleksikan informasi mengenai kualitas laba saat ini. Kualitas laba diukur dengan akrual hasilnya berbanding terbalik, yakni perusahaan dengan abnormal akrual yang tinggi menunjukkan laba perusahaan berkualitas rendah, sedangkan perusahaan dengan akrual yang rendah menunjukkan laba perusahaan berkualitas tinggi.

Pemisahan antara agen dengan principal berpotensi menimbulkan konfli kepentingan yang efeknya mempengaruhi kualitas laba yang dilaporkan. Pihak manajemen yang mempunyai kepentingan tertentu akan cenderung menyusun laporan laba yang sesuai dengan tujuannya dan bukan demi untuk kepentingan prinsipal. Dalam kondisi seperti ini diperlukan suatu mekanisme pengendalian yang dapat mensejajarkan perbedaan kepentingan antara kedua belah pihak. Mekanisme corporate governance memiliki kemampuan dalam kaitannya menghasilkan suatu laporan keuangan yang memiliki kandungan informasi laba.

Salah satu motivasi perusahaan, adalah meningkatkan nilai perusahaan. Konflik keagenan yang mengakibatkan adanya sifat opportunistic manajemen akan mengakibatkan rendahnya kualitas laba. Rendahnya kualitas laba akan dapat membuat kesalahan pembuatan keputusan para pemakainya seperti investor dan kreditor, sehingga nilai perusahaan akan berkurang (Siallagan dan Machfoedz, 2006: 123).

Laporan Keuangan salah satunya berfungsi memberikan informasi laba, dimana penting perannya sebagai sinyal performance suatu perusahaan guna pembuatan berbagai keputusan penting oleh pengguna informasi. Laba yang tidak menunjukkan informasi yang sebenarnya tentang kinerja manajemen dapat 
menyesatkan pihak pengguna laporan. Jika laba seperti ini digunakan oleh investor untuk membentuk nilai pasar perusahaan, maka laba tidak dapat menjelaskan nilai pasar perusahaan yang sebenarnya (Boediono, 2005: 172-191).

Kredibilitas proses penyusunan laporan keuangan seperti halnya menjaga terciptanya sistem pengawasan perusahaan yang memadai serta dilaksanakannya good corporate governance merupakan peran urgen dan strategis dari Komite audit . Pembentukan komite audit diharapkan dapat meningkatkan efektifitas perusahaan, karena komite audit merupakan bagian integral dalam pengendalian internal perusahaan. Tugas komite berhubungan dengan kualitas laporan keuangan, karena komite audit diharapkan dapat membantu dewan komisaris dalam pelaksanaan tugas, yaitu mengawasi proses pelaporan keuangan oleh manajemen. Menurut Teoh dan Wong (1993) dalam Suaryana (2005: 30-35) peran komite audit sangat penting karena mempengaruhi kualitas laba perusahaan yang merupakan salah satu informasi penting yang tersedia untuk publik dan dapat digunakan investor untuk menilai perusahaan.

Struktur dalam perusahaan salah satunya, yaitu dewan komisaris yang memegang peranan sangat penting dalam perusahaan, terutama dalam pelaksanaan good corporate governance. Dewan komisaris merupakan suatu mekanisme mengawasi dan memberikan petunjuk dan arahan pada pengelola perusahaan (FCGI, 2001). Komposisi dewan komisaris merupakan salah satu karakteristik dewan yang berhubungan dengan kandungan informasi laba. Melalui perannya dalam menjalankan fungsi pengawasan, komposisi dewan dapat mempengaruhi pihak manajemen dalam menyusun laporan keuangan sehingga dapat diperoleh suatu laporan laba yang berkualitas (Boediono, 2005: 1-5).

Peran komisaris independen diharapkan mampu meningkatkan kinerja dewan komisaris sehingga tercipta good corporate governance di dalam perusahaan. Manfaat Corporate Governance (CG) akan dilihat dari premium yang bersedia dibayar oleh investor atas ekuitas perusahaan (harga pasar). Jika ternyata investor bersedia membayar lebih mahal, maka nilai pasar perusahaan yang menerapkan good Corporate Governance (CG) juga akan lebih tinggi dibanding perusahaan yang tidak menerapkan atau mengungkapkan praktik good corporate governance mereka (Kusumawati dan Riyanto, 2005).

Struktur kepemilikan (kepemilikan manajerial dan kepemilikan institusional) oleh beberapa peneliti dipercaya mampu mempengaruhi jalannya perusahaan yang pada akhirnya berpengaruh pada kinerja perusahaan dalam mencapai tujuan perusahaan, yaitu maksimalisasi nilai perusahaan. Hal ini disebabkan oleh karena adanya kontrol yang mereka miliki (Wahyudi dan Pawestri, 2006).

Konflik kepentingan antara prinsipal dan agen dapat dikurangi dengan meningkatkan kepemilikan manajerial dalam suatu perusahaan (Jensen dan Meckling, 1976). Ross et al (1999) dalam Siallagan dan Machfoedz (2006) menyatakan bahwa semakin besar kepemilikan manajemen dalam perusahaan maka manajemen akan cenderung untuk berusaha meningkatkan kinerjanya demi kepentingan pemegang saham dan kepentingannya sendiri. Tekanan dari pasar modal menyebabkan 
perusahaan dengan kepemilikan manajerial yang rendah akan memilih metode akuntansi yang meningkatkan laba yang dilaporkan, yang sebenarnya tidak mencerminkan keadaan ekonomi dari perusahaan yang bersangkutan (Boediono, 2005). Dengan memperbesar kepemilikan saham perusahaan oleh manajemen (managerial ownership), kepentingan pemilik atau pemegang saham akan dapat disejajarkan dengan kepentingan manajer.

Peran mekanisme kepemilikan institusional, efektivitas pengelolaan sumber daya perusahaan oleh manajemen dapat diketahui dari informasi yang dihasilkan melalui reaksi pasar atas pengumuman laba. Kepemilikan institusional memiliki kemampuan untuk mengendalikan pihak manajemen melalui proses monitoring secara efektif sehingga mengurangi tindakan manajemen melakukan manajemen laba. Persentase saham tertentu yang dimiliki oleh institusi dapat mempengaruhi proses penyusunan laporan keuangan yang tidak menutup kemungkinan terdapat akrualisasi sesuai kepentingan pihak manajemen (Boediono, 2005).

\section{B. PEMBAHASAN}

\section{Pengertian Corporate Governance (CG)}

Corporate governance berkaitan dengan bagaimana para investor yakin bahwa manajer akan memberikan keuntungan bagi mereka, yakin bahwa manajer tidak akan mencuri atau menggelapkan atau menginvestasikan ke dalam proyek-proyek yang tidak menguntungkan berkaitan dengan dana yang telah ditanamkan oleh investor, dan berkaitan dengan bagaimana para investor mengontrol para manajer (Ujiyantho dan Pramuka, 2007: 1-24). Dengan kata lain corporate governance diharapkan dapat berfungsi untuk menekan atau menurunkan biaya keagenen (agency cost).

Menurut Forum for Corporate Governance in Indonesia (FCGI, 2001: 22-23), corporate governance diartikan sebagai berikut: "seperangkat peraturan yang mengatur hubungan antara pemegang saham, pengurus (pengelola) perusahaan, pihak kreditur, pemerintah, karyawan serta para pemegang kepentingan intern dan ekstern lainnya yang berkaitan dengan hak-hak dan kewajiban mereka, atau dengan kata lain suatu sistem yang mengatur dan mengendalikan perusahaan."

FCGI merumuskan tujuan dari corporate governance adalah untuk menciptakan nilai tambah bagi semua pihak yang berkepentingan (stakeholders). Corporate Governance (CG) yang mengandung empat unsur penting, yaitu keadilan, transparansi, pertanggungjawaban dan akuntabilitas, diharapkan dapat menjadi suatu jalan dalam mengurangi konflik keagenan. Dengan adanya tata kelola perusahaan yang baik, diharapkan nilai perusahaan akan dinilai dengan baik oleh investor.

Terdapat dua hal yang harus ditekankan konsep Good Corporate Governance (GCG) pertama, pentingnya hak pemegang saham untuk memperoleh informasi dengan benar dan tepat waktunya dan, kedua, kewajiban perusahaan untuk melakukan pengungkapan (disclosure) secara akurat, tepat waktu, transparan terhadap semua informasi kinerja perusahaan, kepemilikan, dan 
stakeholde (Kaihatu, 2006).

Perspektif hubungan keagenan merupakan dasar yang digunakan untuk corporate governance. Jensen dan Meckling (1976: 305-360) menyatakan bahwa hubungan keagenan (agency relationship) adalah sebuah kontrak dimana satu atau lebih pemilik (prinsipal, dalam hal ini pemegang saham) memperkerjakan seseorang (agen) untuk melaksanakan pekerjaan untuk kepentingan mereka dengan cara mendelegasikan beberapa kebijakan dalam pengambilan keputusan.

Pengertian prinsipal meliputi kreditor, karyawan, pemerintah serta masyarakat. Dalam agency-stakeholder theory dikatakan bahwa kreditur, pelanggan, pemasok, masyarakat, dan pemerintah juga disebut sebagai prinsipal. Jansen dan Meckling (1976: 305-360) mengungkapkan bahwa hubungan implisit antara pemegang saham dan manajer hanya salah satu dari hubungan keagenan, hubungan keagenan yang lain meliputi hubungan antara manajer dengan berbagai kelompok yang memiliki kepentingan terhadap perusahaan atau disebut stakeholder.

Adanya pemisahan kepemilikan dan pengendalian akan mendorong manajer (agen) untuk melakukan sesuatu yang berbeda dengan keinginan prinsipal. Baik prinsipal maupun agen diasumsikan mementingkan diri mereka sendiri, yaitu untuk memaksimalkan utilitas subjektif mereka, tetapi juga menyadari kepentingan umum mereka. Dalam melaksanakan tugas manajerialnya, manajemen memiliki tujuan pribadi yang seringkali berlawanan dengan tujuan prinsipal untuk memaksimalkan kekayaan para pemegang saham. Agen berusaha untuk memaksimalkan fee kontraktual yang diterimanya tergantung pada tingkat upaya yang diperlukan. Prinsipal berusaha untuk memaksimumkan returns dari penggunaan sumber dayanya tergantung pada fee yang dibayarkan kepada agen. Pemisahan kepemilikan dan pengendalian organisasi dinamakan konflik kepentingan (agency conflict).

Konflik kepentingan yang mungkin terjadi karena perbedaan kepentingan antara prinsipal dan agen dapat menyebabkan timbulnya biaya keagenan. Menurut Jensen dan Meckling (1976: 305-360) terdapat tiga jenis biaya keagenan yaitu :

1. Biaya pengawasan (monitoring cost) : Biaya yang dikeluarkan oleh prinsipal untuk mengawasi agen sehingga dapat membatasi aktivitas yang menyimpang dari agen yang disebabkan perbedaan kepentingan antara agen dan prinsipal.

2. Biaya yang mengikat (bonding cost) : Sumber daya perusahaan yang dibelanjakan agen untuk menjamin bahwa agen tidak akan bertindak yang dapat merugikan prinsipal atau untuk meyakinkan bahwa prinsipal akan memberikan kompensasi jika dia benar-benar melakukan tindakan tersebut.

3. Biaya residu (residual cost) : Nilai uang yang ekuivalen dengan pengurangan kesejahteraan yang dialami prinsipal jika terjadi divergensi antara keputusan-keputusan yang dapat memaksimalkan kesejahteraan agen. 
Eisenhardt (1989: 35-54) dalam Ujiyantho dan Pramuka (2007: 24) menyatakan bahwa teori agensi menggunakan tiga asumsi sifat manusia yaitu: (1) manusia pada umumnya mementingkan diri sendiri (self-interest), (2) manusia memiliki daya pikir terbatas mengenai persepsi masa mendatang (bounded rationality), dan (3) manusia selalu menghindari resiko (risk averse).

\section{Prinsip-Prinsip Good Corporate Governance}

a. Transparansi (transparency)

Konsep corporate governance harus menjamin adanya pengungkapan yang tepat waktu dan akurat untuk setiap permasalahan yang berkaitan dengan perusahaan. Pengungkapan ini meliputi informasi mengenai keadaan keuangan, kinerja perusahaan, kepemilikan, dan pengelolaan perusahaan. Disamping itu, informasi yang diungkapkan harus disusun, diaudit, dan disajikan sesuai dengan standar yang berkualitas tinggi. Manajemen juga diharuskan meminta auditor eksternal melakukan audit yang bersifat independen atas laporan keuangan (OECD, 2004).

Linan dalam Hastuti (2005), berpendapat bahwa prinsip transparasi meliputi pengungkapan informasi yang bersifat penting, informasi harus disiapkan, diaudit dan diungkapkan sejalan dengan pembukuan yang berkualitas, penyebaran informasi harus bersifat adil, tepat waktu dan efisien. Sehingga para pengelola perbankan syariah harus meletakkan tanggung jawab yang sebesar-besarnya terhadap keselamatan dana yang telah dipercayakan oleh nasabah kepada mereka (wibowo, 2009).

b. Pertanggungjawaban

Responsibilitas adalah adanya tanggung jawab pengurus dalam manajemen, pengawasan manajemen serta pertanggungjawaban kepada perusahaan dan para pemegang saham (OECD, 2004). Prinsip ini tercermin dalam kerangka corporate governance harus memberikan pengakuan terhadap hak-hak stakeholders, seperti yang telah ditentukan dalam undangundang, dan mendorong kerjasama yang aktif antara perusahaan dengan para stakeholders tersebut dalam rangka menciptakan lapangan kerja, kesejahteraan masyarakat dan kesinambungan usaha.

Prinsip pertanggungjawaban ini meliputi antara lain, menjamin hak pihak-pihak berkepentinggan, para pihak yang berkepentingan hasrus mempunyai kesempatan untuk mendapatkan ganti rugi yang efektif atas pelanggaran hak-hak mereka, dibukanya mekanisme pengembangan prestasi bagi keikutsertaan pihak yang berkepentingan, dan jika perlu, para pihak yang berkepentingan harus memiliki akses terhadap informasi yang relevan (Linan dalam Hastuti, 2005).

c. Akuntabilitas 
Menurut Linan dalam Hastuti (2005), bahwa prinsip akuntabilitas ini meliputi perngetian bahwa anggota Dewan Direksi harus bertindak mewakili kepentingan perusahaan dan para pemegang saham, penilaian yang bersifat independen terlepas dari manajemen, dan adanya akses terhadap informasi yang relevan, akurat dan tepat waktu.

Dalam prakteknya perbankan syariah juga harus benar-benar dijalankan sesuai dengan prinsip syariah. Dalam hal ini terdapat peran penting Dewan Pengawas Syariah dalam mengawasi operasional perbankan syariah agar tetap berjalan sesuai dengan ketentuan syariah (Wibowo, 2009).

\section{d. Profesional}

Dalam menjalankan kwajiban sesuai dengan aturan yang berlaku dalam suatu organisasi atau perusahaan. Prinsip professional tidak memiliki keberpihakan kesalah satu kepentingan (independen).

\section{Mekanisme Corporate Governance}

Menurut teori keagenan untuk mengatasi masalah ketidakselarasan kepentingan salah satunya adalah melalui pengelolaan perusahaan yang baik (good corporate governance). Corporate governance merupakan suatu mekanisme yang digunakan untuk memastikan bahwa supplier keuangan, misalnya pemegang saham (shareholders) dan pemberi pinjaman (bondholder) dari perusahaan memperoleh pengembalian dari kegiatan yang dijalankan manajer (Setiawan, 2006: 163-172).

Ada empat mekanisme gorporate governance yang sering dipakai dalam berbagai penelitian mengenai corporate governance yang bertujuan untuk mengurangi konflik keagenan, yaitu komite audit, komisaris independen, kepemilikan institusional, kepemilikan manajerial (Rachmawati, 2007: 22).

Definisi corporate governance menurut Forum for Corporate Governance in Indonesia (FCGI, 2001: Edisi Ke-3 jilid 1) adalah seperangkat peraturan yang menetapkan hubungan antara pemegang saham, pengurus, pihak kreditur, pemerintah, karyawan serta para pemegang kepentingan intern dan ekstern lainnya sehubungan dengan hak-hak dan kewajiban mereka, atau dengan kata lain sistem yang mengarahkan dan mengendalikan perusahaan.

Pandangan teori keagenan dimana terdapat pemisahan antara pihak agen dan prinsipal yang mengakibatkan munculnya potensi konflik dapat mempengaruhi kualitas laba yang dilaporkan. Pihak manajemen yang mempunyai kepentingan tertentu akan cenderung menyusun laporan laba yang sesuai dengan tujuannya dan bukan demi untuk kepentingan prinsipal. Dalam kondisi seperti ini diperlukan suatu mekanisme pengendalian yang dapat mensejajarkan perbedaan kepentingan antara kedua belah pihak. Mekanisme corporate governance memiliki kemampuan dalam kaitannya menghasilkan suatu laporan keuangan yang memiliki kandungan informasi laba.

Good Corporate Governance (GCG) merupakan praktek terbaik yang biasa 
dilakukan oleh suatu perusahaan yang berhasil yang mengacu pada bauran antara alat, mekanisme dan struktur yang menyediakan kontrol dan akuntabilitas yang dapat meningkatkan economic enterprises dan kinerja perusahaan serta mendorong perusahaan melakukan penciptaan nilai yang diproksi dengan kinerja masa depan. Praktek terbaik ini mencakup praktik bisnis, aturan main, struktur proses dan prinsip yang dimiliki.

Good Corporate Governance (GCG) merupakan syarat bagi perusahaan untuk mendapatkan kepercayaan bagi investor di pasar modal. Perusahaan dengan corporate governance yang baik akan dapat meningkatkan nilai perusahaan bagi pemegang saham. Hal ini karena visi, misi dan strategi perusahaan dinyatakan secara jelas, nilai-nilai perusahaan serta kode etik disusun untuk memastikan adanya kepatuhan seluruh jajaran perusahaan, terdapat kebijakan untuk menghindari benturan kepentingan dan transaksi dengan pihak ketiga yang tidak tepat, risiko perusahaan dikelola dengan baik dan terdapat sistem pengendalian dan monitoring yang baik (Sayidah, 2007: 1-19).

\section{KESIMPULAN}

Good Corporate Governance (GCG) merupakan implementasi terbaik yang biasa dilakukan oleh suatu perusahaan yang berhasil yang mengacu pada bauran (mix) antara alat, mekanisme dan struktur yang menyediakan kontrol dan akuntabilitas yang dapat meningkatkan economic enterprises dan kinerja perusahaan serta mendorong perusahaan melakukan penciptaan nilai yang diproksi dengan kinerja masa depan. Praktek terbaik ini mencakup praktik bisnis, aturan main, struktur proses dan prinsip yang dimiliki.

Salah satu faktor penghambat mengapa Good Corporate Governance (GCG) sangat lemah pada implementasinya karena kurang transparannya pengelolaan perusahaan dengan kontrol publik yang sangat lemah dan terkonsentrasinya pemegang saham besar pada beberapa keluarga menyebabkan campur tangan pemegang saham mayoritas pada manajemen perusahaan sangat terasa dan menimbulkan konflik kepentingan yang sangat menyimpang dari norma tata kelola perusahaan.

\section{DAFTAR PUSTAKA}

Boediono, Gideon SB. (2005). Kualitas Laba: Studi Pengaruh Mekanisme Corporate Governance dan Dampak Manajemen Laba dengan Menggunakan Analisis Jalur. Simposium Nasional Akuntansi (SNA) VIII Solo.

Forum for Corporate Governance in Indonesia. (2001) . Peranan Dewan Komisaris dan Komite Audit dalam Pelaksanaan Corporate Governance. Seri Tata Kelola 


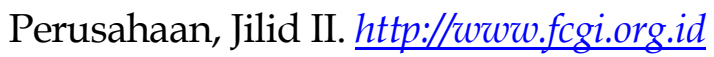

Hastuti, Theresia Dwi. (2005). Hubungan Antara Good Corporate Governance dan Struktur Kepemilikan dengan Kinerja Keuangan. Simposium Nasional Akuntansi (SNA) VIII Solo.

Jensen, Michael C. dan W. H. Meckling. (1976). Theory of The Firm: Managerial Behaviour, Agency Cost and Ownership Structure. http://papers.ssm.com

Kaihatu, Thomas S. (2006). Good Corporate dan Penerapannya di Indonesia. Jurnal manajemen dan Kewirausahaan, Vol. 8, No. 1. Hal: 1-9.

Kusumawati, Dwi Novi dan Bambang Riyanto LS. (2005). Corporate Governance dan Kinerja : Analisis Pengaruh Compliance Reporting dan Struktur Dewan Terhadap Kinerja. Simposium Nasional Akuntansi (SNA) VIII Solo.

OECD. (2004). OECD Principle of Corporate Governance.

Mayangsari, Sekar. (2009). Bukti Empiris Pengaruh Spesialisasi Industri Auditor terhadap Earnings Response Coefficient. Jurnal Riset Akuntansi Indonesia. Volume 7. Nomor.2 Hal. 154-178.

Midiastuty, Pratana Puspa dan Mas'ud Machfoedz. (2003). Analisis Hubungan Mekanisme Corporate Governance dan Indikasi Manajemen Laba. Simposium Nasional Akuntansi (SNA) VI Surabaya.

Nurim, Yavida. (2003). Analisis Kecepatan Nilai Ekuilibrium Earnings pada Periode Sebelum dan Selama Krisis Moneter. Simposium Nasional Akuntansi VI (SNA) Surabaya.

Rachmawati, Andri. (2011). Pengaruh Investment Opportunity Set dan Mekanisme Corporate Governance Terhadap Kualitas Laba dan Nilai Perusahaan. Skripsi S1Fakultas Ekonomi Universitas Sebelas Maret Surakarta, Tidak Dipublikasikan.

Sayidah, Nur. (2011). Pengaruh Kualitas Corporate Governance Terhadap Kinerja Perusahaan Publik (Studi Kasus Peringkat 10 Besar CGPI Tahun 2003, 2009, 2005). JAAI. Volume 11. No. 1. Hal. 1-19.

Suaryana, Agung. 2005. Pengaruh Komite Audit Terhadap Kualitas Laba. Simposium Nasional Akuntansi (SNA) VIII Solo.

Setiawan, Wawan. (2006). Analisis Pengaruh Mekanisme Corporate Governance Terhadap Kualitas Laba. Jurnal Akuntansi dan Bisnis, Volume. No.2. Hal. 163-172.

Siallagan, Hamonangan dan Mas'ud Machfoedz. (2006). Mekanisme Corporate Governance, Kualitas Laba dan Nilai Perusahaan. Simposium Nasional Akuntansi (SNA) IX 
Padang.

Susiana dan Arleen Herawaty. (2011). Analisis Pengaruh Independensi, Mekanisme Corporate Governance, dan Kualitas Audit Terhadap Integritas Laporan Keuangan. Simposium Nasional Akuntansi X Makassar.

Suranta, Eddy dan Mas'ud Machfoedzs. (2003). Analisis Struktur Kepemilikan, Nilai Perusahaan, Investasi dan Ukuran Dewan Direksi. Simposium Nasional Akuntansi (SNA) VI Surabaya.

Ujiyantho, Muh. Arief dan Bambang Agus Pramuka. (2011). Mekanisme Corporate Governance, Manajemen Laba dan Kinerja Keuangan. Simposium Nasional Akuntansi (SNA) X Makassar.

Wahyudi, Untung dan Hartini Prasetyaning Pawestri. (2006). Implikasi Strktur Kepemilikan Terhadap Nilai Perusahaan : Dengan Keputusan Keuangan Sebagai Variabel Intervening. Simposium Nasional Akuntansi (SNA) IX Padang.

Wibowo, Ari. (2009). Membangun Perbankan Syari'ah Menuju Good Corporate Governance. www.pesantren.uii.ac.id.

Yee, Kenton K. (2006). Earnings Quality and the Equity Risk Premium: A Benchmark Model. http://papers.ssrn.com 